\title{
PEDAGOGICAL CONCEPTUALISATION OF CONTENT KNOWLEDGE IN TEACHING ART MUSIC RELATED ESP
}

\author{
Darko Kovačević \\ University of East Sarajevo, Faculty of Electrical Engineering/Academy of Music, Bosnia and Hercegovina \\ E-Mail: dax1978@gmail.com
}

\begin{abstract}
Pedagogical conceptualisation of content knowledge is a significant component of the present time teaching of ESP at higher institutions, because usually the lessons in general English are not sufficient for a successful accomplishment of the teaching process assignments and learning process outcomes. In the case of art music related ESP, it is necessary, at the teacher's side, to have a certain amount of content knowledge in the field of art music in order to be able to find and prepare the appropriate lesson materials and organise the entire teaching process, so that the knowledge is conceptualised and properly used for English language teaching and learning. Such knowledge and its pedagogical conceptualisation will be the central topics of the paper, preceded by some introductory facts on art music and texts on art music, pedagogical content knowledge and the art music related ESP.
\end{abstract}

Key words: ESP, art music, pedagogical content knowledge, teaching, conceptualisation

\section{INTRODUCTION}

The definition of music as art which uses sound and is expressed by it, sets out music as a temporary art whose "realisations are received (by hearing) and experienced (by spirit) as a kind of process of sound events in the flow of time, so that they can be connected into a whole only through the consciousness of a listener, who memorises what has passed, makes connections with what is being heard at the moment and anticipates what is coming (or knows that, on the basis of earlier listening of the same music" (Despić 2007, 11).

On the other hand, art music, sometimes also known as "classical" or "serious" music, presents the music "which has the features of authentic art to a largest degree: 1 . Striving for formal perfection; 2. Ability of expressing more complex emotional and thoughtful states of a human; 3. Individual features of creation with more emphasised affiliation to a stylistic epoch in the development of art; 4 . At least, to a certain degree, the existing originality in the form and thematic (contents); 5. Authorship which is set out clearly and protected by the law; 6 , Professional and technical level necessary in the process of creation, performance and, to a large degree (as a precondition) in the process of acceptance (in the actual case of listening) of a work of art as well, which, to a larger or lower degree, assumes a special education of the people who deal with that music actively or passively" (Plavša 1972: 617).

In other words, art music, perceived in this way, presents an opposition to popular music and its numerous styles and genres, and is distinguished from it both on the basis of the stated artistic characteristics and on the basis of the continuity of written records

Submitted September $1^{\text {st }}, 2018$, accepted for publication October $31^{\text {st }}, 2018$ 
which has existed from the creation of early notation systems to the present day, visible in the form of sheet music (music scores) of musical compositions (Kovačević 2017: 35)

Due to the fact that musical notation is a unique system of signs used in the same way worldwide, the existence of music scores enables a direct insight into the music from different epochs and the creation of particular composers who belong to the epochs, both in terms of analysis and in terms of their performance, with the possibility of permanent archiving of the sound recordings made during the live performance of music from the existing scores.

To describe, present or show different phenomena relating to art music, various theoretical disciplines have been developed parallel to the development of the music itself, which, depending on the course and range of their interest, perceive art music from different perspectives and present their results in the form of different types of texts which are, in terms of contents and terminology, primarily oriented towards the community of professionals in the field of art music. Among the phenomena discussed in such texts the primary place is occupied by musical works, perceived through listening, from the score or by combining the two, and composers, their lives, education, compositional techniques and positions they occupy within the periods (epochs) in the development of the art of music they belong to. The periods, with their characteristics, specificities, forms, genres and representatives also have their place within the texts on art music. It is the same with the performers on different instruments, music theoreticians and analysts. Finally, these texts also include the publications from the wide area of musical pedagogy, used in the teaching of music culture, playing on particular instruments and vocational musical subjects (Solfeggio, Harmony, Musical Forms, Music Theory, Music Instruments, Musical Arranging, etc.) at all levels of education (Kovačević 2017: 35-36)

As such, they share some characteristics in terms of linguistic properties, contents and topics which make them special, unique and oriented towards the discourse community of professional musicians, i.e. the persons whose professional and educational path has touched some of the aspects of art music, through performance, analysis, theory, pedagogical engagement or the combination of two or more mentioned aspects.

The students of music, at the university level, within the academies and faculties of music, surely belong to such a community, and, as the English language has evidently become the communication standard in the world of today in all the fields of human activity, including art music and art in general, as well as a sort of standardized language for writing and publishing of professional books, papers and articles on a global level, the key role of vocational English lessons existing within their curricula is to make it possible for them to use the English language on a level which is satisfactory for various professional purposes, especially for professional communication and reading and writing of different forms, types and genres of professional texts. Such lessons are an integral part of art music related courses of English for Special Purposes (ESP). However, to implement them appropriately and with effect, it is often necessary, at the lecturer's side, to gain a certain amount of additional knowledge within the terminology and areas/subjects of art music and to conceptualise some specific strategies in organising, introducing and presenting the content of (planned) teaching materials to students. For that purpose, the lecturer's pedagogical content knowledge is of extraordinary importance. 


\section{Pedagogical Content KNOWLedge}

The term pedagogical content knowledge (often abbreviated in available literature as PKT) was introduced by Lee Sherman, an American educational psychologist. He identified the following types of knowledge that a teacher should have in order to be successful in accomplishing the tasks and functions:

- content knowledge;

- general pedagogical knowledge, with special reference to those broad principles and strategies of classroom management and organization that appear to transcend subject matter;

- curriculum knowledge, with particular grasp of the materials and programs that serve as 'tools of the trade' for teachers;

- pedagogical content knowledge, that special amalgam of content and pedagogy that is uniquely the province of teachers, their own special form of professional understanding knowledge of learners and their characteristics;

- knowledge of educational contexts, ranging from workings of the group or classroom, the governance and financing of school districts, to the character of communities and cultures; and

- knowledge of educational ends, purposes, and values, and their philosophical and historical grounds. (Shulman, 1987: 8)

Observing it within the stated categories, Shulman describes the pedagogical content knowledge by saying that it "represents the blending of content and pedagogy into an understanding of how particular topics, problems, or issues are organized, represented, and adapted to the diverse interests of learners, and presented for instruction" (Shulman 1987: 8). Richards and Schmidt define it as "a teacher's knowledge of subject matter and the ability to represent it in a way that will facilitate teaching and learning" i.e. something that "refers to knowing how to turn that subject matter into plans for teaching and learning" (Richards and Schmidt 2010: 425). On the other hand, Brophy's definition is partially oriented towards the teacher's use of students' knowledge relating to specific (professional) content, stating that pedagogical content knowledge is "a special form of professional understanding that is unique to teachers and combines knowledge of the content to be taught with knowledge of what students know or think they know about this content and knowledge of how this content can be represented to the students through examples, analogies, etc., in ways that are most likely to be effective in helping them to attain the intended outcomes of instruction" (Brophy 1991: xii). Such a definition is fully applicable to the planning and organisation of an ESP course, where the topics and materials used in lessons are largely oriented towards the linguistic conceptualisation of (mother tongue based) students' professional knowledge within the vocabulary and grammar rules and conventions of a new, foreign language (English), so that it "involves, on the one hand, being aware of the different teaching approaches, methods and techniques and, on the other hand, having a thorough understanding of the different aspects of language including its phonetic, morphologic, syntactic, semantic and pragmatic dimensions" (Benhima 2016: 4). As such, it is an excellent starting point for observing, implementing and applying the concept of pedagogical content knowledge in the teaching of art music related English to the students of higher education institutions in music. 


\section{ART Music RELATEd ESP}

"Positioned within the overarching category of Language for Specific Purposes (LSP), English for Specific Purposes focuses on studying and teaching specialized varieties of English, most often to non-native speakers of English, in advanced academic and professional settings" (Bawarshi and Reiff 2010: 41). Richards and Schmidt define ESP as "the role of English in a language course or programme of instruction in which the content and aims of the course are fixed by the specific needs of a particular group of learners", stating, as the examples, "English for science and technology and English for Nursing" (Richards and Schmidt 2010: 198).

Art music related ESP presents a specific type of ESP where the emphasis is on mastering the use of specific terminology and linguistic structures which are considered as appropriate, understandable and professional within the discourse community of people professionally or educationally involved in art music. Besides the essential knowledge of terminology, i.e. of the English language translation equivalents of terms, expressions and phrases the students have mastered during their professional education, it also involves the similar transfer of knowledge of lexico-grammatical and discursive features of the texts within the art music register, as well as of the most characteristics types and genres of texts, and the topics they may include, from their mother tongue to English. Of course, within that transfer, a balance must be between the language learning and professional components of the teaching process, and the content should be carefully organised in terms of dealing with different aspects and dimensions of language, such as morphology, syntax, semantics, pragmatics, discourse and genre analysis. However, other, more or less extracurricular components, such as the (previous) knowledge of general English, acquired within the system of elementary and secondary education, or the allocated number of lessons per week within a semester or an academic year, are also significant factors in a successful implementation of an ESP course in general and the adjustments of its contents. In all the cases and scenarios, pedagogical content knowledge stands as a very important, almost crucial factor for a successful teaching process which leads to good and stable results.

\section{Pedagogical Content Knowledge in Teaching ARt Music Related ESP}

In accordance with the abovementioned definition of pedagogical content knowledge, from the very beginning of its conceptualisation in the planning and implementation of the teaching process, both teacher's and students' 'sides' and knowledge must be taken into account, assessed and, if necessary, improved. As the first step of any ESP course, the initial emphasis must be put on terminology in mother tongue, in this case the terminology of art music, at least in its narrower sense, which should be a common professional knowledge for all the students, regardless of the year of study, course or department. It is usually, the knowledge related to the essential teaching subjects in the field of art music, such as Music Theory, Harmony, Solfeggio, Musical Forms and Music Instruments.

Another step is to find the translational and semantic equivalents of such terminological items in English. It is due to the fact that music terminology has been standardised in languages all over the world, to such a degree that for many world languages there are even special, dedicated bilingual dictionaries of music (with English 
as the other language), while numerous translations of various musical terms can be found in general bilingual dictionaries as well, it is easy to conclude that such an adaptation of (familiar) terms, words and expressions in a new (English) language should not be a difficult and a long-term process, and the existence and availability of a widely used (especially among the students) global multilingual information system available to everyone, as the Internet of today is, only makes it more efficient and practical. However, in dealing with the terminology of art music in English language, lessons and teaching materials should be prepared and implemented in such a way that they, at the same time, deal with the key issues of English morphology and syntax, and after some time and 'experience' gained by the students, the concepts of semantics and pragmatics should be introduced to them as well, as much as it is possible and purposeful in relation to the knowledge of a group and the general time available for lessons and extracurricular activities within the entire scope and schedule of teaching subjects in a semester/year. Of course, in doing this, authentic and appropriate textual materials, especially in written form, are an extraordinary set of resources for innumerable activities and exercises, both for the improvement of writing skills (starting from dealing with simple words and their organisation into sentences, to the organisation of sentences into smaller meaningful and grammatically correct paragraphs of texts) and for reading comprehension which, during time and practice, may provide an insight into the deeper logic, structure and discursive organisation of longer textual units on art music written in English language, as well as in the identification and analysis of their semantic, pragmatic and textual genres which may be found as characteristic ones within the discourse on art music. On the other hand, the use of (also authentic) spoken textual materials, in the form of recorded conversations, lectures or presentations given by native speakers, may contribute to the improvement of listening skills of students, and, consequently, and accompanied with appropriate classroom activities, with the improvement of their speaking in English on different professional, art music related topics. All the mentioned also contributes to the teaching of translation to students (in both directions) and the improvement of their translation skills and technique, and that is one of the key requirements of a successful ESP course.

At the other, teacher's side in the educational exchange of information which characterises an ESP teaching process, there are also numerous requirements which must be accomplished, even before the beginning of the teaching process itself. It is assumed that the teacher mastered the general content and concepts of the English language during the years of study within the system of higher education, as well as various teaching approaches and methods applicable and useful in the teaching process within the lessons in general English. However, in order to achieve the appropriate results and to accomplish the tasks set by the concept of ESP itself, the teacher has to involve a great deal of carefully selected professional information in the teaching process, i.e. in this case, to gain a new knowledge on the key concepts of art music and use it in lessons as a professional content knowledge.

Among the concepts, the first of them is closely related with the professional knowledge expected at the students' side, relating to the mentioned musical fields/teaching subjects, such as Music Theory, Harmony, Musical Forms, Music Instruments, etc. It should not be done in great detail and on the level of knowledge equivalent or similar to the one the students (should or are expected to) possess, but should be firm and clear enough for getting the basic ideas and knowing the appropriate terminology to understand and describe them. Only thus can it be used in selecting of proper professional materials in the teaching process 
and their implementation in the classroom. Also, particular attention must be given to the situations in which terminological inconsistencies or ambiguous translations/interpretations exist between the students' mother tongue and English, of course if they exist. Another significant concept is the basic but practical knowledge of sheet music itself, in terms of knowing how to name and read the notes and other signs within and outside the staff system, and also to get familiar with the ways of producing the sound on different (types of) music instruments.

A successful and efficient teacher in art music related English for Special Purposes should also be familiar with the most characteristic genres and types of texts which may be found within the discourse on art music (books on art music - theoretical studies, historical overviews, dictionaries and encyclopaedias, collections of texts written by one or more authors, scientific and professional papers from proceedings and journals, and prefaces and afterwords from printed editions of sheet music), as well as with the key topics in general terms which occur in such texts. The topics can be classified in three broad categories:

- life and creation of composers, with the emphasis on their education, works, compositional techniques and the place they occupied within the epoch and style they belonged to;

- introduction, presentation and definition of musical terms, instruments and phenomena;

- analysis of musical works on the basis of different parameters such as melody, harmony, form, performance aspects, genre, or their combinations.

A characteristic of texts on art music, especially the longer ones, is also their general interdisciplinarity, where music topics are closely associated and interwoven with the topics from philosophy, literature, acoustics, aesthetics, linguistics, physics, etc. That is something that an ESP teacher must be aware of in order to select only the exclusively art music related textual materials/parts to be used in the classroom. Finally, it is very important for a teacher to select the professional materials which are fresh, up to date and follow the syllabi of professional subject at least to a certain degree, so that the association of information between the two languages can be performed in real time.

When such a knowledge is gained by the teacher, and the appropriate materials selected, it is easy to use them in a manner in which the 'regular' general English teaching materials are used in the classroom, i.e. to place (conceptualise) them within the scope of the teaching methods adopted and taught during higher education. It is only important to find a balance between the quantity (of materials) and the quality (of their use and the achieved results and effects), and to harmonise it with the students' previous knowledge in English and the time available for lessons.

\section{CONCLUSION}

A large amount of pedagogical content knowledge is absolutely necessary for a successful teacher in the field of art music related ESP, because, in the case of its absence, it would be truly difficult to deal with the requirements and the achievement of required learning outcomes of the ESP course. If enough content knowledge is gained by the teacher, it is easy to put it within the pedagogical framework and apply it in lessons, taking care of the balance between the quantity and quality. It is necessary to start with the things familiar to students, embodied within the terminology, through which essential 
grammar rules (relating to morphology and syntax) are introduced, with a simultaneous enrichment of vocabulary, and then to move gradually towards the longer textual structures, their discursive organisation, semantic and pragmatic features. The notions of genre and text type should come at the end, presented without too many details, but still clearly enough to make the knowledge practically applicable and useful to students. Also, during the entire teaching process the emphasis must be put on the development of students' translation skills, through the translation exercises performed on appropriate and authentic professional texts in both mother tongue and English. Finally, a gradual development of listening and speaking skills must be a consisting and permanently present component of the teaching process, again guided and based on authentic professional textual materials relating to art music.

\section{REFERENCES}

Bawarshi, A. S. and Reiff, M. J. (2010). Genre: An Introduction to History, Theory, Research, and Pedagogy. West Lafayette: Parlor Press.

Benhima, M. (2016). Pedagogical Content Knowledge in Language Education. Available online at https://www.academia.edu/21704399/Pedagogical_Content_Know-ledge_ in_Language_Education, accessed on 30 August 2018.

Brophy, J. (ed.) (1991). Advances in Research on Teaching, Vol. 2. Greenwich, CT: JAI Press.

Despić 2007 - Деспић, Д. (2007). Теорија музике. Београд: Завод за уџбенике

Kovačević D. (2017). Contrastive Linguistic Analysis of Texts on Classical Music in English and Serbian and Its Possible Applications in Professional Environment and ESP, in Stojković N. (ed.) The Journal of Teaching English for Specific and Academic Purposes Vol. 5, No 1, 2017, pp. 35-48.

Plavša, D. (ed.) (1972). Muzička umetnost, Enciklopedijski leksikon - Mozaik znanja. Beograd: Interpres.

Richards J.C. \& Schmidt R. (2010). The Longman Dictionary of Language Teaching and Applied Linguistics. Fourth Edition. London: Pearson Education Limited.

Shulman, L.S. (1986). Those Who Understand: Knowledge Growth in Teaching. Educational Researcher, Vol. 15, No 2, pp. 4-14.

Shulman, L.S. (1987). Knowledge and Teaching: Foundations of the New Reform. Harvard Educational Review, 57, I, pp 1-22. 